\title{
Purification and characterisation of elastase from Staphylococcus epidermidis
}

\author{
N. SLOOT, M. THOMAS, R. MARRE and S. GATERMANN \\ Institute for Medical Microbiology, University of Lübeck, Germany
}

\begin{abstract}
Summary. An elastase of Staphylococcus epidermidis was purified by ion exchange chromatography on CM-Sepharose and characterised. Its $\mathbf{M}_{\mathrm{r}}$ is $c$. $21 \mathrm{kDa}$, its optimal temperature for activity is $42^{\circ} \mathrm{C}$ and the $\mathrm{pH}$ optimum is 6.8 . The enzyme is activated by cysteine and other SH-donators and inhibited by L-trans-epoxy-succinylleucylamido-(4guanidino)butane (E64), an inhibitor of cysteine proteases, but not by 3,4-dichloroisocoumarin (3,4-DCI), an inhibitor of serine proteases. This finding suggests that the elastase of $S$. epidermidis is a cysteine protease. Because $S$. epidermidis elastase degrades human SIgA, IgM, serum albumin, fibrinogen, and fibronectin, this enzyme may be regarded as a virulence factor.
\end{abstract}

\section{Introduction}

Elastases have the unique ability to cleave elastin, a macroprotein present in skin, arteries and lung. Bacterial elastases have been isolated from several bacterial species, such as Pseudomonas aeruginosa ${ }^{1,2}$ and Vibrio cholerae. ${ }^{3}$ Because of their ability also to cleave several human proteins, such as IgG, IgA, IgM and transferrin, as is the case for $P$. aeruginosa elastase, ${ }^{4,5}$ the enzymes are considered to be virulence factors. Recently, an elastase has been described in Staphylococcus aureus and a role in tissue damage has been proposed for it. ${ }^{6}$ Unlike other known elastases, ${ }^{7,8}$ the enzyme from $S$. aureus was found to be a cysteine protease. ${ }^{6}$ The production of elastase by $S$. epidermidis was first described in $1968^{\circ}$ and the presence of the enzyme was subsequently correlated with perifollicular macular atrophy. ${ }^{9} S$. epidermidis produces more elastase than $S$. aureus, ${ }^{10}$ but the enzyme has not yet been characterised. Therefore, the present study was done to isolate, purify and characterise it.

\section{Materials and methods}

\section{Strains}

All experiments were done with $S$. epidermidis ATCC14990. Long term storage was in PY broth (Bacto Yeast-extract $5 \mathrm{~g} / \mathrm{L}$, Bacto peptone $10 \mathrm{~g} / \mathrm{L}$, $\mathrm{NaCl} 5 \mathrm{~g} / \mathrm{L}$, glucose $1 \mathrm{~g} / \mathrm{L}, \quad \mathrm{Na}_{2} \mathrm{HPO}_{4} 1 \mathrm{~g} / \mathrm{L}$, $\mathrm{pH} 7 \cdot 3)^{11}$ containing glycerol $15 \%$ at $-70^{\circ} \mathrm{C}$. Before the experiments, the strain was grown on brain heart

Received 15 Aug. 1991; revised version accepted 12 Dec. 1991. Address for correspondence: Dr N. Sloot, Institut für Medizinische Mikrobiologie, Medizinische Universität zu Lübeck, Ratzeburger Allee 160, D-2400 Lübeck, Germany. infusion (BHI) agar and the identity of subcultures was confirmed with the API(STAPH)-System (Montalieu-Vercieu, France).

\section{Preparation of elastase}

A dialysis membrane technique was used. ${ }^{12}$ Autoclaved dialysis membranes (Spectrapor, Spectrum Medical Industries, Los Angeles, CA, USA) with a cut-off of 12-14 kDa were placed on top of BHI agar plates ( $9 \mathrm{~cm}$ diameter). Strains from long-term storage were subcultured on BHI agar and 40 plates with dialysis membranes were inoculated with a suspension prepared from these cultures. Plates were incubated for $18 \mathrm{~h}$ at $37^{\circ} \mathrm{C}$ in $\mathrm{CO}_{2} 15 \%$ in air. After incubation, bacteria and bacterial products from each plate were harvested from the dialysis membranes in $1 \mathrm{ml}$ of $\mathrm{NaCl} 0.9 \%$. The suspension was centrifuged for $30 \mathrm{~min}$ at $22100 \mathrm{~g}$ to separate bacteria from bacterial products. The supernate was filter-sterilised and the presence of elastase was checked in elastin plateselastin (Sigma, Deisenhofen, Germany) 0.25\%, 0.05 M Tris buffer, pH 7.0, agarose (Difco, USA) $1 \%$ incubated at $37^{\circ} \mathrm{C}$ for $18 \mathrm{~h}$. The zone of clearing was determined. Elastase from porcine pancreas (Sigma) and $\mathrm{NaCl} 0.9 \%$ were used as controls, the elastase being stored at $4^{\circ} \mathrm{C}$ and used within 2 weeks.

\section{Activity of elastase}

Enzyme activity was assessed by incubation with Azocoll (Sigma). Samples (125 $\mu$ l) were added to $1.125 \mathrm{ml}$ of an Azocoll suspension $(10 \mathrm{mg} / \mathrm{ml}$ in $0.1 \mathrm{M}$ phosphate buffer $\mathrm{Na}_{2} \mathrm{HPO}_{4} / \mathrm{NaH}_{2} \mathrm{PO}_{4}, \mathrm{pH} \mathrm{7.0)}$ and incubated at $37^{\circ} \mathrm{C}$ with constant agitation for 15,20 or $40 \mathrm{~min}$. Uncleaved substrate was removed by centrifugation and absorbancy of the supernate was read at 
$520 \mathrm{~nm}$. Enzyme activity in the presence of cysteine (2-8 $\mathrm{mm}$ final concentration), $2 \mathrm{mM}$ mercaptoethanol $2 \mathrm{~mm}$ dithiothreitol, $2 \mathrm{mM}$ EDTA, $\mathrm{Cd}^{2+}, \mathrm{Pb}^{2+}, \mathrm{Hg}^{2+}$, 3,4-dichloroisocoumarin (3,4-DCI, $465 \mathrm{nM})$ and Ltrans-epoxysuccinylleucylamido-(4-guanidino)butane (E64, $280 \mathrm{nM}$ ) (all from Sigma) was also assessed.

\section{Determination of temperature and $\mathrm{pH}$ optima}

The Azocoll technique was used as described above and the samples were incubated at $6^{\circ} \mathrm{C}, 23^{\circ} \mathrm{C}$, $32^{\circ} \mathrm{C}, 37^{\circ} \mathrm{C}, 42^{\circ} \mathrm{C}$ and $50^{\circ} \mathrm{C}$ for 30 and $60 \mathrm{~min}$. Elastase samples were also incubated on elastin plates as described above and the $\mathrm{pH}$ of the Tris-buffer was adjusted to $5 \cdot 0,6 \cdot 0,6 \cdot 5,7 \cdot 0,7 \cdot 5$ and $8 \cdot 0$. The activity of elastase was measured as the diameter of the zones of elastin digestion.

\section{Elastase purification}

Purification was achieved by ion-exchange chromatography with a CM-Sepharose CL-6B column $(1.6 \times 20 \mathrm{~cm}$, Pharmacia LKB, Freiburg, Germany), packed and equilibrated with $50 \mathrm{~mm}$ sodium phosphate buffer, $\mathrm{pH} 6.0$, according to the specifications of the manufacturer; $10 \mathrm{ml}$ of crude preparation $(2.5 \mathrm{mg} / \mathrm{ml})$ were applied to the column and eluted at $35 \mathrm{ml} / \mathrm{h}$ with a $\mathrm{NaCl}$ gradient $(0-0.6 \mathrm{M}, 400 \mathrm{ml})$. Elastase activity of all fractions $(3.5 \mathrm{ml})$ was checked by the plate assay, and peak fractions were analysed by SDS-PAGE (see below).

Protein content was assessed with the BioRad assay (BioRad, München, Germany) with bovine serum albumin as the standard.

\section{$S D S-P A G E$}

Electrophoresis of proteins in the presence of sodium dodecyl sulphate (SDS) was done in poly- acrylamide gels (PAGE) according to the method of Laemmli $^{13}$ and the concentrations of running and stacking gels were 12 and $6 \%$, respectively. Samples containing 5-6 $\mu \mathrm{g}$ of protein were heated at $100^{\circ} \mathrm{C}$ for $3 \mathrm{~min}$ in sample buffer ( $62.5 \mathrm{~mm}$ Tris buffer, $\mathrm{pH} 6.8$, SDS 2\%, 2-mercaptoethanol 5\%, glycerol $10 \%$, bromophenol blue $0.001 \%$ ) and applied to the gel. Proteins were stained with silver according to the method of Blum et al. ${ }^{14}$

Cleavage of human $\operatorname{IgG}, \operatorname{IgM}$, sIgA, fibronectin, fibrinogen, and human serum albumin (all from Sigma) was assessed in solutions which contained $1 \mathrm{mg} / \mathrm{ml}$ in distilled water; $10 \mu \mathrm{l}$ of each solution was mixed with $40 \mu \mathrm{l}$ of purified elastase $(275 \mu \mathrm{g} / \mathrm{ml})$ and, after incubation for $18 \mathrm{~h}$ at $37^{\circ} \mathrm{C}$, cleavage products were analysed by SDS-PAGE.

Cleavage of collagen was examined with collagen plates prepared by the same means as the elastase plates but containing collagen (collagen type I from bovine achilles tendon, Sigma) $0.25 \%$. Again, the zone of clearing was determined and compared with that for $\mathrm{NaCl} 0.9 \%$ after incubation at $37^{\circ} \mathrm{C}$ for $18 \mathrm{~h}$.

The hydrolysis of carbobenzoxy-L-phenylalanylL-leucyl- $\alpha$-glutamyl-4-nitranilid (CBZ-Phe-Leu-Glu$p$ NA; Boehringer, Mannheim, Germany) was tested at a final concentration of $0.17 \mathrm{~mm}$ as described by Potempa et al. ${ }^{6}$ The generation of $p$-nitroanilin was measured at $410 \mathrm{~nm}$ after incubation for 130 and $180 \mathrm{~min}$. For quantitative assessment, a molar extinction coefficient of 8800 was used for $p$-nitroanilin. ${ }^{15}$

All experiments with human immunoglobulins were repeated at least five times, with other substrates at least twice with enzyme from several preparations.

\section{Results}

The activity of $S$. epidermidis elastase was increased four-fold by the presence of SH-donators (cysteine,

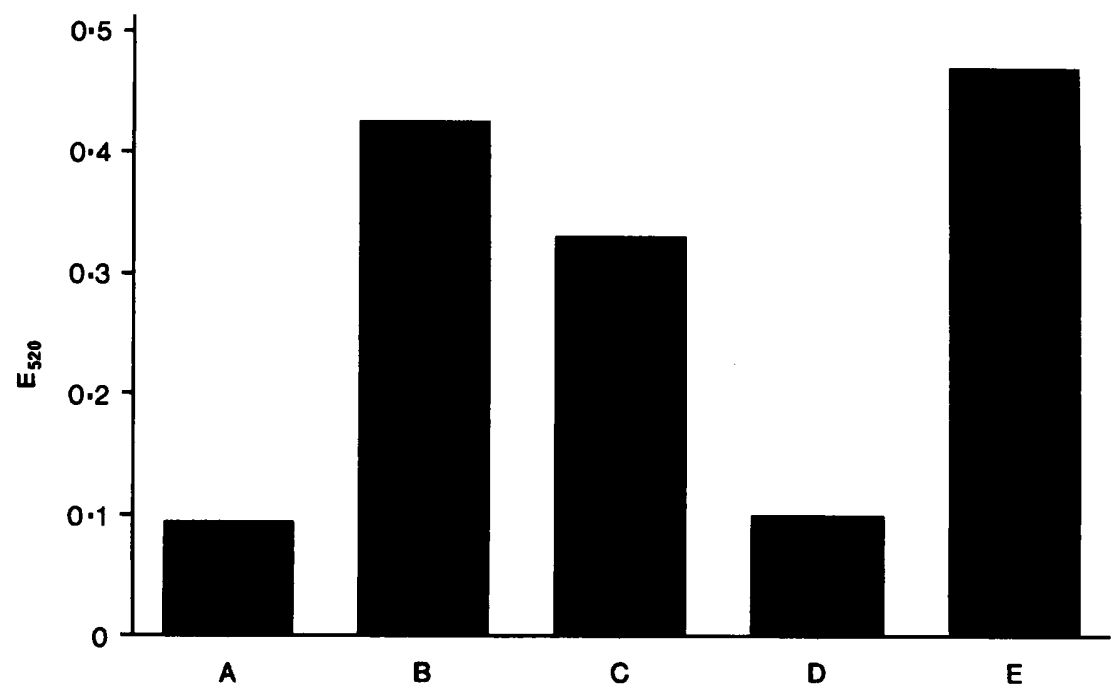

Fig. 1. Proteolytic activity of $S$. epidermidis elastase; $125 \mu \mathrm{l}$ of crude elastase ( $480 \mathrm{mg}$ of protein $/ \mathrm{ml})$ was incubated with $12.5 \mathrm{mg}$ of Azocoll in phosphate buffer, $\mathrm{pH} 7.0$, for $20 \mathrm{~min}$ at $37^{\circ} \mathrm{C}$. A: S. epidermidis crude elastase; B; with 2 mM cysteine, C: with 2 mM mercaptoethanol. D: with 2 mM EDTA. E: with 2 mM cysteine and 2 mM EDTA. 


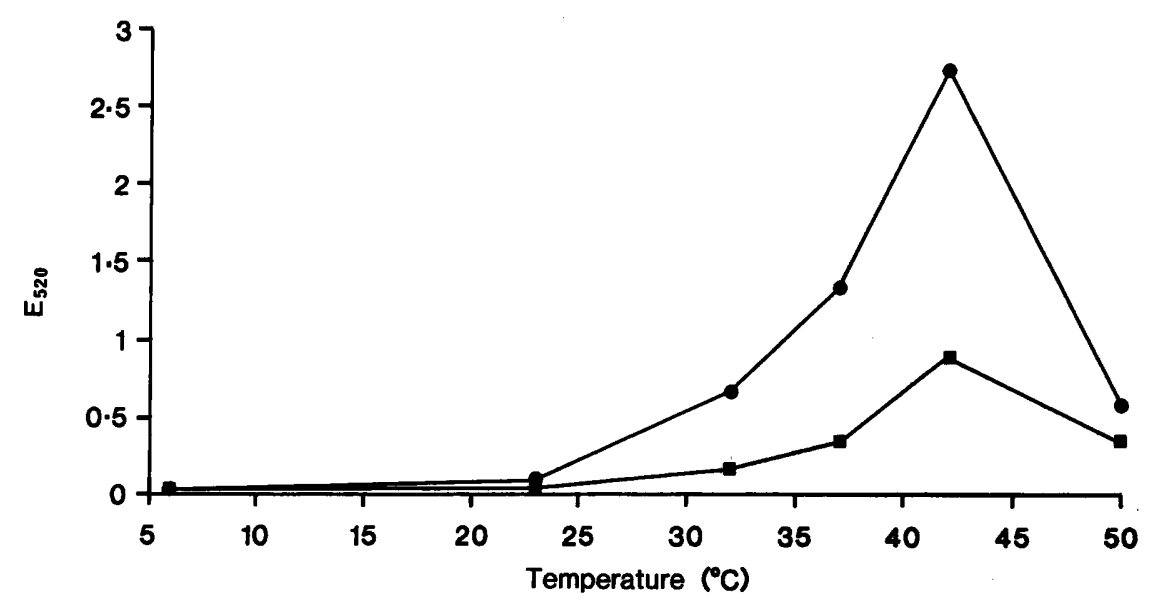

Fig. 2. Effect of temperature on the activity of S. epidermidis elastase; $125 \mu \mathrm{l}$ of crude elastase was incubated with $12.5 \mathrm{mg}$ of Azocoll in phosphate buffer $\mathrm{pH} 7.0$ for $30(\square)$ and $60(\mathbf{O}) \mathrm{min}$.

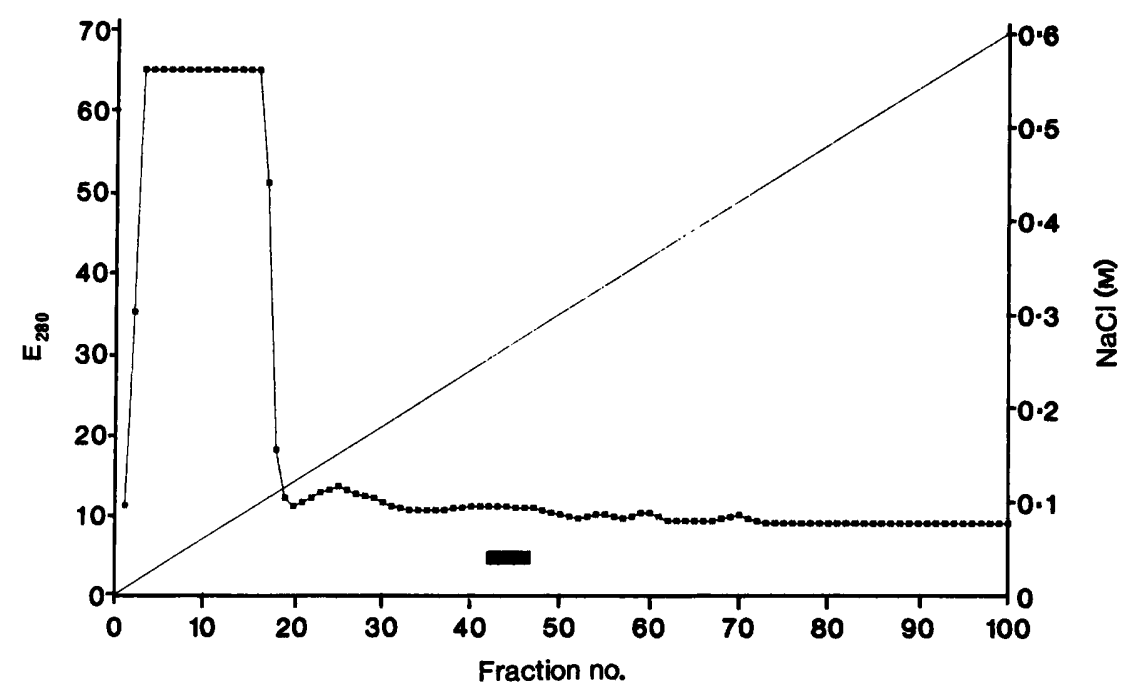

Fig. 3. Purification of $S$. epidermidis elastase with CM-Sepharose CL-6B; $10 \mathrm{ml}$ of crude elastase in sodium phosphate buffer, $\mathrm{pH} 6.0$, was applied to the column $(1.6 \times 20 \mathrm{~cm})$, which had been equilibrated with sodium phosphate buffer $(\mathrm{pH} 6.0)$ and eluted with a gradient from 0 to $0.6 \mathrm{M} \mathrm{NaCl}$. Bar indicates fractions with elastolytic activity.

mercaptoethanol, dithiothreitol) and the addition of $2 \mathrm{~mm}$ EDTA, alone or in combination with $2 \mathrm{mM}$ cysteine, had no effect on enzyme activity (fig. 1).

The presence of E64 inhibited elastase activity and at a concentration of $280 \mathrm{~nm}$ there was a complete loss of proteolysis; the degree of inhibition depended on the concentration of E64. The addition of 3,4-DCI had no significant effect on elastase activity. The enzyme showed no significant activity below $23^{\circ} \mathrm{C}$; proteolysis was most efficient at $42^{\circ} \mathrm{C}$ (fig. 2), with a distinct loss at $50^{\circ} \mathrm{C}$. Proteolytic activity was determined at a range of $\mathrm{pH}$ values $(5 \cdot 0-8.0)$ and maximum activity was observed at $\mathrm{pH} 6.8$.

Purification to homogeneity was achieved by ion exchange chromatography on CM-Sepharose and fractions with peak activity yielded a single band in SDS-PAGE of c. $21 \mathrm{kDa}$ (fig. 5). Elastase eluted at a $\mathrm{NaCl}$ concentration of $0 \cdot 25-0.28 \mathrm{M}$ (fig. 3) and no additional proteolytic fractions were found.

Incubation of purified elastase with human $\operatorname{sigA}$, IgM (fig. 4) and human serum albumin (HSA) (fig. 5) showed an incomplete degradation with the appearance of new bands in SDS-PAGE, but no subunit of sIgA was completely cleaved. In the case of $\operatorname{IgM}$ a

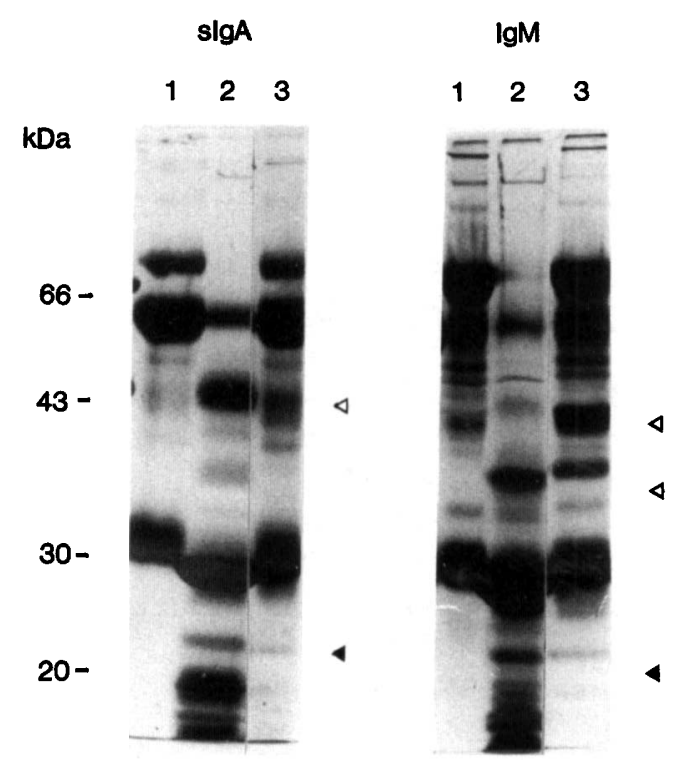

Fig. 4. Cleavage of human immunoglobulins by $S$. epidermidis elastase. Substrate proteins $(5 \mu \mathrm{g})$ were incubated $\left(18 \mathrm{~h}, 37^{\circ} \mathrm{C}\right)$ with crude or purified elastase $(5 \mu \mathrm{g})$. Products were analysed by SDSPAGE and the gel was stained with silver. Lane 1: human immunoglobulin; 2: human immunoglobulin and crude elastase; 3 : human immunoglobulin and purified elastase; elastase $(\varangle)$ and digestion products $(\triangleleft)$ are indicated. 


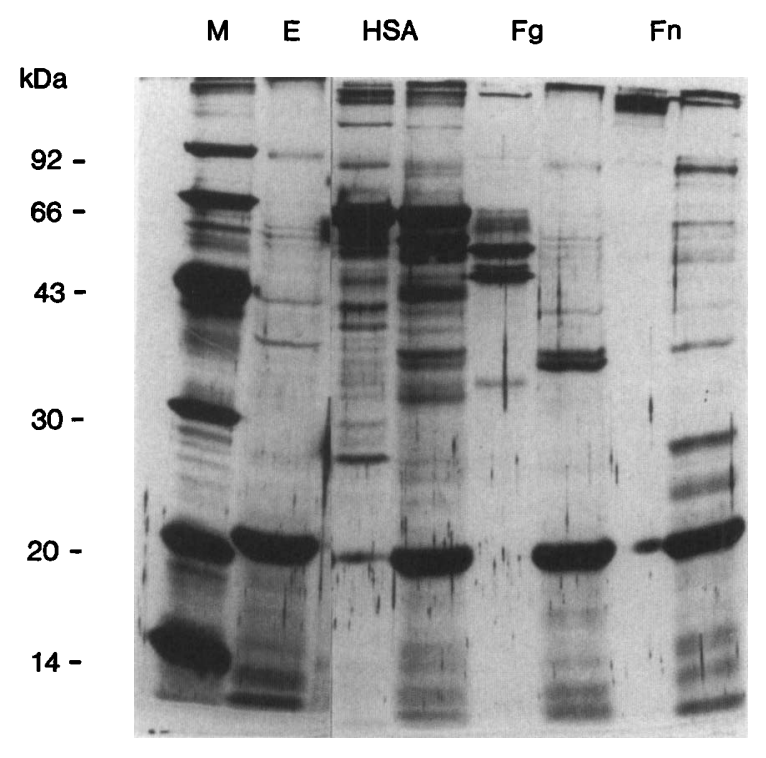

Fig. 5. Cleavage of human proteins by $S$. epidermidis elastase. Substrate proteins $(5 \mu \mathrm{g})$ were incubated $\left(18 \mathrm{~h}, 37^{\circ} \mathrm{C}\right)$ with purified elastase $(5 \mu \mathrm{g})$. Products were analysed by SDS-PAGE and the gel was stained with silver. M: marker proteins; E: purified elastase; HSA: human serum albumin; $\mathrm{Fg}$ : fibrinogen, $\mathrm{Fn}$ : fibronectin; purified elastase was present in the second lane for each of the substrates.

single new band of $c .31 \mathrm{kDa}$ was found when crude elastase was used (fig. 4), whilst a number of new bands resulted from degradation of HSA (fig. 5). In contrast fibronectin $(440 \mathrm{kDa})$ and all three subunits of human fibrinogen $(67,56$ and $47 \mathrm{kDa})$ were completely digested, with the production of at least five degradation products $(94,64,56,28$ and $24 \mathrm{kDa})$ with the former and two break-down products with the latter (both $55 \mathrm{kDa}$ ) (fig. 5). Elastase generated $0.11 \mathrm{mM}$ of $p$-nitroanilin after incubation with CBZPhe-Leu-Glu- $p \mathrm{Na}$ for $2 \mathrm{~h}$ and $0.12 \mathrm{~mm}$ after $3 \mathrm{~h}$, indicating cleavage of 65 and $70 \%$ of the substrate. These experiments were done in triplicate and results deviated by less than $1 \%$. Degradation of collagen was not observed in any experiment.

\section{Discussion}

Production of elastase by $S$. epidermidis was first described in $1968^{\circ}$ and the distribution and biochemical properties of the enzyme in clinical isolates were investigated later. ${ }^{16,17} \mathrm{~A}$ role for $S$. epidermidis elastase as a virulence factor was postulated in these reports, but cleavage of human proteins was not demonstrated.

In this investigation, we purified and characterised elastase from $S$. epidermidis and identified human proteins that are cleaved by the enzyme. The enzyme has an apparent $\mathbf{M}_{\mathrm{r}}$ of $c .21 \mathrm{kDa}$, which is larger than that reported for the $S$. aureus enzyme $(13 \mathrm{kDa}){ }^{6} S$. epidermidis elastase is activated by SH-donors, such as cysteine or mercaptoethanol, and inactivated by heavy metal ions such as $\mathrm{Cd}^{2+}, \mathrm{Pb}^{2+}$ or $\mathrm{Hg}^{2+}$ but not by EDTA. Furthermore, the enzyme is inhibited by E64, a specific inhibitor of cysteine proteases, but not by 3,4-DCI, which inhibits serine proteases. Thus, $S$. epidermidis elastase can be regarded as a cysteine proteinase, as is the case for the $S$. aureus enzyme ${ }^{6}$ but in contrast to most other bacterial elastases so far described which are serine or metallo-proteinases.

In addition to the biochemical characterisation, we have shown that $S$. epidermidis elastase is able to cleave several human proteins, including immunoglobulins. This finding is in contrast to that of Plaut, ${ }^{18}$ who reported that staphylococci did not produce IgAproteases. In our cleavage experiments, crude elastase digested human proteins more efficiently than purified elastase and, in the case of $\operatorname{sIgA}$, complete digestion was observed only with the former. As no other proteolytic fraction was detected during column chromatography, it is likely that cleavage was due to the elastase. Purification of the enzyme appeared to reduce elastase activity, probably by removing unknown auxiliary substances.

Elastase may be involved in the pathogenicity of $S$. epidermidis in a number of ways. Both $\operatorname{SIgA}$ and IgM are degraded by the enzyme and inactivation of these immunoglobulins may assist bacteria in the early phase of infection by depressing the host defence mechanisms. ${ }^{19,20} S$. epidermidis can adhere to plastic surfaces, and subsequent colonisation often leads to bacteraemia. ${ }^{21}$ As these surfaces are covered with albumin, fibrinogen and fibronectin in vivo, it is possible that elastase removes or modifies protein surface films on indwelling devices and thus helps the organism to adhere more effectively. Fibrinogen and fibronectin are also important in wound healing since they supply an essential network for blood coagulation. Thus, the ability of elastase to cleave fibrinogen and fibronectin may play a role in the development of wound infection. ${ }^{21}$

The elastase of $S$. aureus is known to cleave only CBZ-Phe-Leu-Glu-pNA from a range of synthetic substrates, ${ }^{6}$ and in this investigation $S$. epidermidis elastase produced a similar result. $S$ epidermidis elastase cleaved $65 \%$ and $70 \%$ of the synthetic substrate after incubation for 1 and $2 \mathrm{~h}$ respectively. The apparent loss of activity may be due to instability of the protein in the incubation mixture or a consequence of substrate depletion. In addition, it cannot be excluded that one of the breakdown products is inhibitory to the enzyme.

\section{References}

1. Obernesser HJ, Döring G, Botzenhart K. Extrazelluläre Toxine von Pseudomonas aeruginosa, I. Reinigung und Charakterisierung zweier Exoproteasen. Zentralbl Bakteriol Hyg A 1981 ; 249: 76-88.

2. Heck LW, Alarcon PG, Kulhavy RM, Morihara K, Russell MW, Mestecky JF. Degradation of IgA by Pseudomonas aeruginosa elastase. J Immunol 1990; 144: 2253-2257.

3. Tripathi KK, Kaur M, Gupta M, Gupta KG. Production and partial characterization of elastase of Vibrio cholerae Inaba. Zentralbl Bakteriol 1989; 271: 431-441. 
4. Döring G, Obernesser HJ, Botzenhart K. Extrazelluläre Toxine von Pseudomonas aeruginosa, II. Einwirkung zweier gereinigter Proteasen auf die menschlichen Immuglobuline IgG, IgA und sekretorisches IgA. Zentralbl Bakteriol Hyg, A 1981; 249: 89-98.

5. Döring G, Pfestorf M, Botzenhart K, Abdallah MA. Impact of proteases on iron uptake of Pseudonomas aeruginosa pyoverdin from transferrin and lactoferrin. Infect Immun 1988; 56: 291-293.

6. Potempa J, Dubin A, Korzus G, Travis J. Degradation of elastin by a cysteine proteinase from Staphylococcus aureus. $J$ Biol Chem 1988; 263: 2664-2667.

7. Kothary MH, Kreger AS. Production and partial characterization of an elastolytic protease of Vibrio vulnificus. Infect Immun 1985; 50: 534-540.

8. Wretlind B, Pavlovskis OR. Pseudonomas aeruginosa elastase and its role in pseudomonas infections. Rev Infect Dis 1983; 5 Suppl. 5: 998-1004.

9. Varadi DP, Saqueton AC. Elastase from Staphylococcus epidermidis. Nature 1968; 218 : 468-470.

10. Murphy RA. Elastase production by oral staphylococci. $J$ Dent Res 1974; 53: 832-834.

11. Gatermann S, Marre R, Heesemann J, Henkel W. Hemagglutinating and adherence properties of Staphylococcus saprophyticus: epidemiology and virulence in experimental urinary tract infection of rats. FEMS Microbiol Immunol $1988 ; 47: 179-168$.

12. Hartman DP, Murphy RA. Production and detection of staphylococcal elastase. Infect Immun 1977; 15: 59-65.
13. Laemmli UK. Cleavage of structure proteins during the assembly of the head of bacteriophage T4. Nature 1970; 227: 680-685.

14. Blum $\mathrm{H}$, Beier $\mathrm{H}$, Gross $\mathrm{H}-\mathrm{J}$. Improved silver staining of plant proteins, RNA and DNA in polyacrylamide gels. Electrophoresis 1987; 8: 93-99.

15. Nakajima K, Powers JC, Ashe BM, Zimmerman M. Mapping the extended substrate binding site of cathepsin $G$ and human leukocyte elastase. Studies with peptide substrates related to the $\alpha_{1}$-protease-inhibitor reactive site. $J$ Biol Chem 1979; 254: 4027-4032.

16. Janda JM. Elastolytic activity among staphylococci. J Clin Microbiol 1986; 24: 945-946.

17. Watts JL, Naidu AS, Wadström T. Collagen binding, elastase production, and slime production associated with coagulase-negative staphylococci isolated from bovine intramammary infections. J Clin Microbiol 1990; 28: 580-583.

18. Plaut AG. The IgA1 proteases of pathogenic bacteria. Annu Rev Microbiol 1983; 37: 603-622.

19. Maeda H, Molla A. Pathogenic potentials of bacterial proteases. Clin Chimica Acta 1989; 185: 357-368.

20. Mestecky H, McGhee JR. Immunogiobulin A (IgA): molecular and cellular interactions involved in IgA biosynthesis and immune response. Adv Immunol 1987; 40: 153-245.

21. Wadström $T$. Molecular aspects on pathogenesis of wound and foreign body infections due to staphylococci. Zentralbl Bakteriol Microbiol Hyg A 1987; 266: 191-211. 